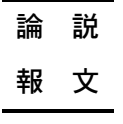

動電学的土䁃浄化法による重金属の浄化効率に及㳯す 電極配列の影響

\section{Effect of Electrode Configuration on Cleanup Efficiency of Heavy Metals by Electrokinetic Soil Remediation}

\author{
Masakazu NIINAE $^{1}$, Yuji $\mathrm{AOKI}^{2}$ and $\mathrm{Kenji}_{\mathrm{AOKI}}{ }^{1}$ \\ ${ }^{1}$ Department of Urban and Environmental Engineering, Kyoto University, Kyoto 606-8501, Japan \\ ${ }^{2}$ Graduate student, Kyoto University, Kyoto 606-8501, Japan
}

Electrokinetic soil remediation by electroosmosis and ionic migration is restricted to soluble substances. At a higher $\mathrm{pH}$, the soil particles sorb more heavy metals, such as cadmium, than at a lower $\mathrm{pH}$ and the precipitation reactions of heavy metals are promoted. Both mechanisms make heavy metals immobile, rendering cleanup more difficult and electrokinetic extraction inefficient. Therefore, the acidification of soils is very important to increase the cleanup efficiencies of heavy metals, such as cadmium by electrokinetic method from contaminated soils. Meanwhile, hexavalent chromium is more mobile and easily soluble. Hexavalent chromium has high solubility in water and exists as chromate, monochromate or dichromate anions depending on the $\mathrm{pH}$ of the solutions. This hexavalent chromium is the chemical form requiring remediation. In this study, cadmium and hexavalent chromium transport are predicted with a simple numerical method in which electrical flow is coupled with hydraulic flow, and the sorption process in the soils is induced in the model. The effects of some factors such as electrode configuration, electric field strength and electrode spacing for saturated soils are investigated using this numerical model. The results obtained this study are summarized as follows:

The two-dimensional electrode configurations containing cathode surrounded by three or more anodes rapidly remove cadmium from soils compared with one-dimensional electrode configuration. Meanwhile, in the removal of hexavalent chromium from soils, the two-dimensional electrode configurations containing anode surrounded by three or more cathodes can be effectively utilized compared with one-dimensional electrode configuration. A larger electrode spacing increases the processing time required, and it was also found that a larger electric field strength reduced the processing time required.

Key words: Electrokinetics, Soil Remediation, Heavy Metals, Electrode Configuration, Numerical Analysis

\section{1. 緒言}

電場を土㙥に作用させることで発生する界面動電現象 を利用した動電学的土壌浄化法は, 原位置で污染土壌・ 地下水から有害物質を分離・除去する技術である。わが 国においては土䁃污染対策法が施行され，新たに土壌環 境基準值として含有量基準值が示され，従来の固化・不 溶化に代わる対策措置として動電学的土䁃浄化法は, 污 染土壤から重金属を分離・除去できる原位置浄化修復法

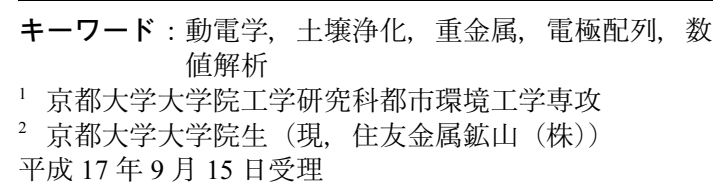

キーワード : 動電学, 土壤浄化, 重金属, 電極配列, 数 値解析

1 京都大学大学院工学研究科都市環境工学専攻

2 京都大学大学院生 (現, 住友金属鉱山 (株))

平成 17 年 9 月 15 日受理

として期待されている。

動電学的土壌浄化法を実際の污染サイトへ適用する場

合, 実規模スケールでの事前の浄化予測解析が重要とな

る。前報 ${ }^{1)}$ に扣いて, 電流 (電位) によって誘起される イオン移動や電気浸透流による物質移動を電気的に発生 する移流と考え, 流量（水頭）に置き換えることにより， 動電学的手法を実規模レベルの污染サイトに適用して浄 化予測が可能な数值解析手法を提案した。また, この解 析手法を用い, カドミウムや鉛などの重金属で活染され た土塞に動電学的手法を適用して浄化する際に, 特に重 要な因子である土壌の酸性化について解析を実施し，操 作因子として重要な電極配列などが土壌の酸性化に与え る影響について検討し，土壤を迅速に酸性化するには， 浄化対象サイトに設置する電極配列を, 陰極を中心に陽 
極を多角形構造になるように配置する必要があることな どを明らかにした。

本研究では，土壌污染対策法で特定有害物質に指定さ れているカドミウムと六価クロムを対象物質として，前 報1)で報告した解析手法を用いることにより，これら重 金属の浄化効率に与える電極配列などの操作因子の影響 について検討し，若干の知見が得られたのでその結果を 報告する。

\section{2. 土壤内での重金属の物理化学的反応}

\section{1 カドミウムの場合}

土畩内に打ける重金属の移動現象を考える場合，考慮 しなければならない物理化学的反応がある。その代表的 な反応として酸-塩基反応と表面吸着反応がある。これら の反応は $\mathrm{pH}$ に依存した反応であり, $\mathrm{pH}$ をコントロール することによって重金属が土壌内をスムーズに移動でき るようにすることが，動電学的手法による浄化を効率的 に行う上で重要になる。本研究では対象物質としたカド ミウムに対し，水の中和反応の他に，水酸化物イオンと の沈殿形成反応扣よび錯形成反応を考えた。各々の反応 を下に示す。

$\mathrm{H}^{+}+\mathrm{OH}^{-} \rightleftarrows \mathrm{H}_{2} \mathrm{O}$

$\mathrm{Cd}^{2+}+2 \mathrm{OH}^{-} \rightleftarrows \mathrm{Cd}(\mathrm{OH})_{2} \downarrow$

$\mathrm{Cd}^{2+}+3 \mathrm{OH}^{-} \rightleftarrows \mathrm{Cd}(\mathrm{OH})_{3}^{-}$

また，各々の化学平衡式は次のようになる。

$\left[\mathrm{H}^{+}\right]\left[\mathrm{OH}^{-}\right]=K_{\mathrm{w}}$

$\left[\mathrm{Cd}^{2+}\right]\left[\mathrm{OH}^{-}\right]^{2}=K_{\mathrm{s}}$

$$
\frac{\left[\mathrm{Cd}(\mathrm{OH})_{3}^{-}\right]}{\left[\mathrm{Cd}^{2+}\right]\left[\mathrm{OH}^{-}\right]^{3}}=\beta_{3}
$$

ここで， $K_{\mathrm{w}}$ は水のイオン積， $K_{\mathrm{s}}$ は溶解度積， $\beta_{3}$ は安 定度定数を示す。次に，カドミウムの全濃度 $[\mathrm{Cd}]_{\mathrm{total}}=5.0$ $\left(\mathrm{mol} / \mathrm{m}^{3}\right)$, 水のイオン積 $K_{\mathrm{w}}=1.0 \times 10^{-8}\left(\left(\mathrm{~mol} / \mathrm{m}^{3}\right)^{2}\right)$ ，水酸 化カドミウムの溶解度積 $K_{\mathrm{s}}=2.51 \times 10^{-5}\left(\left(\mathrm{~mol} / \mathrm{m}^{3}\right)^{3}\right)^{2)}$ 扎よ び安定度定数 $\beta_{3}=20.0\left(\left(\mathrm{~mol} / \mathrm{m}^{3}\right)^{-3}\right)^{2)}$ を用いて各カドミウム 化学種の分布と $\mathrm{pH}$ の関係を求めた。その結果を Fig. 1 に 示す。Fig. 1 から分かるよらに, $\mathrm{pH} 7$ 付近で $\mathrm{Cd}^{2+}$ と $\mathrm{Cd}(\mathrm{OH})_{2}$ の存在比が逆転し，また $\mathrm{Cd}(\mathrm{OH})_{3}^{-}$の生成は全体を通して 汪とんぞ見られなかった。本研究に打いては，陰極井戸 の $\mathrm{pH}$ を 7 に固定することで, 土壤への水酸化物イオン の流出を防止し，土壤 $\mathrm{pH}$ が常に酸性側になるように設 定した ${ }^{1,3,4)}$ 。この操作により $\mathrm{Cd}^{2+}$ 以外の化学種の生成を 防止でき，水酸化物の生成を考慮する必要がなくなる。

次に，粘土鉱物による表面吸着現象と陽イオン交換反 応 ${ }^{5-7)}$ について考光る。一般的な土壌環境では土粒子は負 に帯電して扣り，陽イオン化している重金属は土粒子表 面に Coulomb 力により吸着されている。また，土粒子と

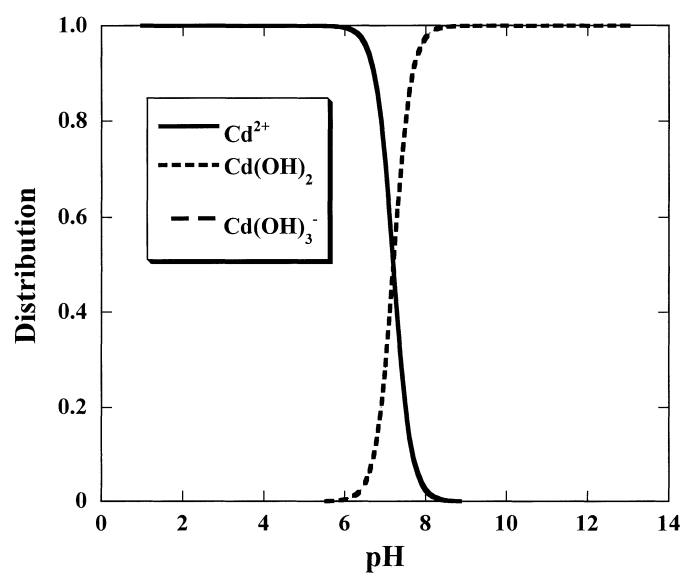

Fig. 1 Distribution of cadmium species as a function of $\mathrm{pH}$. $[\mathrm{Cd}]_{\text {total }}: 5.0 \mathrm{~mol} / \mathrm{m}^{3}$

重金属イオンの間に働くもら一つの力に, 分子間力（van der Waals 力）がある。Coulomb 力は分子間力よりも弱い が到達距離が長い。このため, 重金属イオンはすべて土 粒子表面に密着せず，表面近傍（電気二重層）に束縛さ れて存在する傾向がある。

二重層中の陽イオンは，新しく溶液中に導入された他 の陽イオンによって可逆的に置き換えられたり, 交換さ れたりする。土粒子の負電荷の総量は，通常陽イオン交 換容量 (CEC: Cation Exchange Capacity，単位は慣習的に $\mathrm{meq} / \mathrm{g}$ で示される）と呼ばれている。陽イオン交換容量 は粘土含有量のみでなく，土粒子の比表面積と電荷密度 に規定され，土壤中でのイオンの移動や保持に強く影響 する。また，陽イオンの種類が異なれば，当然その価数， イオン半径，水和性にも差があるので，その吸着力の大 きさや吸着のしやすさも異なり，交換の難易が生じる。 一般的には，イオン半径が小さい注に゙，また，価数が大 きいほぞ，そのイオンはより土粒子表面の近くに，そし てょり強く吸着される。一方，水和イオン半径が大きい ほど，そのイオンは土粒子表面から離れて吸着され，そ の吸着力は弱くなる。このよらにイオン吸着特性はどの 陽イオンに対しても等しいのではなく，ある陽イオンを 他の陽イオンよりも好んで吸着する。このような特性を 陽イオン選択性とよぶ。陽イオン選択性にはいくつかの 定義があるが，最も広く用いられる指標に選択係数があ る。次に, カドミウムと水素イオンの交換反応式を示す。

$$
\mathrm{CdX}_{2}+2 \mathrm{H}^{+} \rightleftarrows \mathrm{Cd}^{2+}+2 \mathrm{HX}
$$

ここで, $\mathrm{CdX}_{2}$ 抢よび $\mathrm{HX}$ は土粒子に吸着した陽イオン を示す。この反応の選択係数 $K_{\mathrm{Cd} / \mathrm{H}}$ は次式で示される。

$K_{\mathrm{Cd} / \mathrm{H}}=\frac{\alpha_{\mathrm{HX}^{2}} \alpha_{\mathrm{Cd}^{2+}}}{\alpha_{\mathrm{CdX}_{2}} \alpha_{\mathrm{H}^{+}}{ }^{2}}$

ここで， $\alpha$ は成分の活量を示す。 
粘土鉱物に抢ける水素イオンの選択性は非常に大き い。また，カドミウムイオンとアルカリ，アルカリ土類 金属イオンを比較すると, カドミウムイオンに著しい選 択吸着が認められる。カドミウムイオンは, 溶液中のカ ルシウムイオンの濃度を高めても脱着および交換はほと んど起こらず，なかなか溶脱されない。一方，カドミウ ムイオンより選択性の大きい水素イオン濃度を高める と, カドミウムイオンは水素イオンと交換される ${ }^{5,8)}$ 。

本研究に拈いては, 陰極井戸の $\mathrm{pH}$ 調節によって酸 - 塩 基反応を考慮する必要はないが，もともと土壤に吸着し ているカドミウムを水素イオンによる陽イオン交換反応 によって土畩間隙に溶出させる必要がある。ここでは, 本研究で用いた土壤 $\mathrm{pH}$ とカドミウムの遅延係数の関係 について考学る。まず, 式（7）㧊よび式（8）に拈いて, 吸着イオンに対しては活量の代わりに土粒子上の $\mathrm{CdX}_{2}$ および $\mathrm{HX}$ のモル分率（ $x_{\mathrm{CdX}_{2}}$ および $\left.x_{\mathrm{HX}}\right)$ を用いて,

$$
K_{\mathrm{Cd} / \mathrm{H}}^{\mathrm{V}}=\frac{\alpha_{\mathrm{Cd}^{2+}} x_{\mathrm{HX}}^{2}}{\alpha_{\mathrm{H}^{+}}{ }^{2} x_{\mathrm{CdX}_{2}}}
$$

という係数を定義する。これは, Vanselow の選択係数と 呼ばれている5。ここで, 例えば土粒子に吸着した HX の モル分率は, 次式で表される。

$$
x_{\mathrm{HX}}=\frac{\left[\mathrm{H}^{*}\right]}{\left[\mathrm{H}^{*}\right]+\left[\mathrm{Cd}^{*}\right]}
$$

ただし， $\left[\mathrm{H}^{*}\right]$ と $\left[\mathrm{Cd}^{*}\right]$ は土粒子に吸着した物質のモル 濃度 $(\mathrm{mol} / \mathrm{kg})$ を示す。

次に, $\alpha_{\mathrm{Cd}^{2+}}$ 《 $\alpha_{\mathrm{H}^{2+}}$ で, 溶液中に他のイオンが存在しない と仮定すると, 水素イオンは 1 価であるため, 吸着物質 のモル濃度と当量濃度は等しく, $C E C \cong\left[\mathrm{H}^{*}\right]$ となる。こ の近似值を式 (9) に代入し, $K_{\mathrm{d}}=\left[\mathrm{Cd}^{*}\right] / \alpha_{\mathrm{Cd}^{2}}$ とすると,

$$
K_{\mathrm{d}}=\frac{C E C}{\alpha_{\mathrm{H}^{+}}{ }^{2} K_{\mathrm{Cd} / \mathrm{H}}^{\mathrm{V}}}
$$

が得られる。また, Henry 型の吸着等温式を仮定した場 合の遅延係数 $R_{\mathrm{d}}$ は次式で示される。

$$
\begin{aligned}
& R_{\mathrm{d}}=1+K_{\mathrm{d}} \frac{\rho_{\mathrm{d}}}{\theta} \\
& \text { 式 (11) を式 (12) に代入すると, } \\
& R_{\mathrm{d}}=1+\frac{\rho_{\mathrm{d}}}{\theta} \frac{C E C}{\alpha_{\mathrm{H}^{+}}{ }^{2} K_{\mathrm{Cd} / \mathrm{H}}^{\mathrm{V}}}
\end{aligned}
$$

となり, $\mathrm{pH}$ と遅延係数の関係が得られる。ここで, $\rho_{\mathrm{d}}$ は 土壤の乾燥密度 $\left(\mathrm{kg} / \mathrm{m}^{3}\right), \theta$ は体積含水率を示す。

粘土鉱物には, 結晶格子内に存在する永久電荷に加光 て, 粘土粒子の表面電荷が存在する。前者の電荷は, 消 滅することなく常に存在し, 粒子の周囲の溶液によって 影響を受けることはない。一方, 後者の電荷は, 周囲の 溶液の $\mathrm{pH}$ の值に依存する。粘土の構造に起因する電荷 （永久電荷）は一般に負であるが, 端面に生じる電荷は低 い $\mathrm{pH}$ では正になることもある。これらの負電荷の総量
は $C E C$ であり，また，表面電位はゼー夕電位（（電位） で近似されている。粘土鉱物は土粒子による重金属の吸 着で主要な役割をする鉱物である。本研究ではゼータ電 位の $\mathrm{pH}$ 依存性の強いカオリナイトをモデル粘土鉱物と して採用した。流動電位法を用いて測定されたカオリナ イトの 電位 $(\mathrm{mV})$ と $\mathrm{pH}$ の関係は, Lorenzによって次 式で与えられている9

$$
\zeta=-38.6+281 e^{-0.48 \mathrm{pH}}
$$

式（14）より，pH4から 5 の間に等電点が存在し，そ れより低い $\mathrm{pH}$ 值においてカオリナイト表面が正に帯電 することになる。したがって, カオリナイトの場合, こ の領域では $C E C$ がほぼ零となることが推察される。ま た， $C E C$ と 電位の間に相関性があるとし， CEC b式 （14）の関係に従って変化すると仮定した。そこで, 本研 究においては, Wei-Zi Wang らの吸着実験 ${ }^{10)}$ から求めた 選択係数 $K_{\mathrm{Cd} / \mathrm{H}}^{\mathrm{V}}\left(=3.15 \times 10^{5} \mathrm{~m}^{3} / \mathrm{mol}\right)$ が常に一定と仮定し, Wei-Zi Wang らの吸着実験で得られた $C E C$ と式（14）の 関係から求めた $C E C$ を式（13）に代入することで各 $\mathrm{pH}$ に扣忷る遅延係数 $R_{\mathrm{d}}$ を求めた。Fig. 2 に, 砂質粘土土謮 $\left(\rho_{\mathrm{d}}=2.65 \times 10^{3} \mathrm{~kg} / \mathrm{m}^{3}, \theta=0.35\right)$ に対する $\mathrm{pH}$ とカドミウム の遅延係数 $R_{\mathrm{d}}$ の関係を示す。さらに, この $\mathrm{pH}-R_{\mathrm{d}}$ 曲線 を Table 1 に示すよらに範囲ごとに区切り, 解析におけ るカドミウムの遅延係数に反映した。これより, pH4.4 以下では遅延係数が 1 となり, すべてのカドミウムイオ ンが陽イオン交換反応により脱着し, 間隙水中に溶出す ることになる。

\section{2 六価クロムの場合}

六価クロムは有害であることに加え, 水に溶解しやす く, 移動性が高いことから, 浄化が強く望まれる物質の 一つである。水に溶解した六価クロムは, $\mathrm{pH}$ に応じて

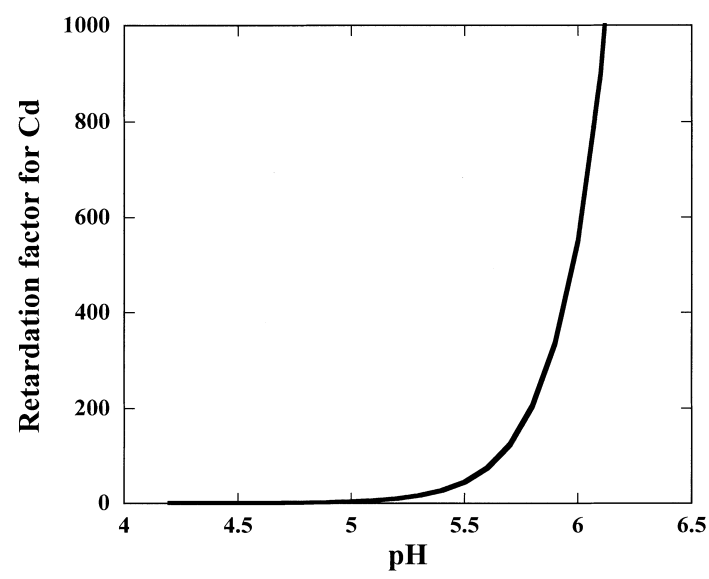

Fig. 2 Relationship between retardation factor of cadmium and $\mathrm{pH}$. 
新苗 正和・青木 悠二・青木 謙治

Table 1 Retardation factor of cadmium used in numerical analysis.

\begin{tabular}{|c|c|}
\hline $\mathrm{pH}$ & Retardation factor $\left(R_{\mathrm{d}_{\mathrm{Cd}}}\right)$ \\
\hline$\sim 4.4$ & 1 \\
\hline $4.4 \sim 5.0$ & 3 \\
\hline $5.0 \sim 5.3$ & 10 \\
\hline $5.3 \sim 5.6$ & 50 \\
\hline $5.6 \sim$ & 500 \\
\hline
\end{tabular}

$\mathrm{HCrO}_{4}^{-}, \mathrm{CrO}_{4}^{2-}$ 抢よび $\mathrm{Cr}_{2} \mathrm{O}_{7}^{2-}$ として存在する。六価ク口 ムと水素イオンとの反応を以下に示す。

$$
\begin{aligned}
& \mathrm{H}_{2} \mathrm{CrO}_{4} \rightleftarrows \mathrm{H}^{+}+\mathrm{HCrO}_{4}^{-} \\
& \mathrm{HCrO}_{4}^{-} \rightleftarrows \mathrm{H}^{+}+\mathrm{CrO}_{4}^{2-} \\
& 2 \mathrm{HCrO}_{4}^{-} \rightleftarrows \mathrm{Cr}_{2} \mathrm{O}_{7}^{2-}+\mathrm{H}_{2} \mathrm{O}
\end{aligned}
$$

また，各々の化学平衡式は次のようになる。

$$
\frac{\left[\mathrm{H}_{2} \mathrm{CrO}_{4}^{-}\right]}{\left[\mathrm{H}^{+}\right]\left[\mathrm{HCrO}_{4}^{-}\right]}=K_{\mathrm{HCrO}_{4}}^{\mathrm{H}}
$$

$$
\begin{aligned}
& \frac{\left[\mathrm{HCrO}_{4}^{-}\right]}{\left[\mathrm{H}^{+}\right]\left[\mathrm{CrO}_{4}^{2-}\right]}=K_{\mathrm{CrO}_{4}}^{\mathrm{H}} \\
& \frac{\left[\mathrm{Cr}_{2} \mathrm{O}_{7}^{2-}\right]}{\left[\mathrm{HCrO}_{4}^{-}\right]}=K
\end{aligned}
$$

ここで, 六価クロムの全濃度を $[\mathrm{Cr}]_{\mathrm{total}}=1.0 \times 10^{-3}(\mathrm{~mol} /$ $\left.\mathrm{m}^{3}\right)$ とし, $K_{\mathrm{HCrO}_{4}}^{\mathrm{H}}=6.30 \times 10^{-3}\left(\mathrm{~mol} / \mathrm{m}^{3}\right)^{-1}{ }^{2)}, K_{\mathrm{CrO}_{4}}^{\mathrm{H}}=3.16 \times$ $10^{3}\left(\mathrm{~mol} / \mathrm{m}^{3}\right)^{-12)}$ および $K=43.6^{2)}$ を用いて各々の化学種の 分布と $\mathrm{pH}$ の関係を求めた。その結果を Fig. 3 に示す。六 価クロムは $\mathrm{pH} 6.5$ 以上では $\mathrm{CrO}_{4}^{2-}$ が主な化学種となり, $\mathrm{pH} 6$ 以下では $\mathrm{Cr}_{2} \mathrm{O}_{7}^{2-}$ が主な化学種となる。本研究では六 価クロムの浄化の場合には陽極井戸の $\mathrm{pH}$ を中性に保持 し，陽極側からの酸の発生を抑制し，土壤 $\mathrm{pH}$ が常に 6.5 以上になるよらに設定することで，全ての六価クロムが $\mathrm{CrO}_{4}^{2-}$ として存在すると仮定して解析を実施した。

また，土壤中では，粘土鉱物と水中の重金属イオンと の間に静電気的な力が働いて，負電荷には陽イオン，正 電荷には陰イオンが吸着され，土粒子による重金属イオ ンの吸着が行われる。しかし，通常は，陰イオンの吸着 量は小さく，カオリナイトの場合，式（14）から分かる ように, 対象とする $\mathrm{pH}$ 領域 ( $\mathrm{pH} 6.5$ 以上) ではゼータ 電位は負になることから, 陰イオン交換容量 (AEC: Anion Exchange Capacity）は零と見なせる ${ }^{11)}$ 。式（13）におい て，CECを $A E C$ と置き換えることで六価クロムの遅延 係数 $R_{\mathrm{d}}$ は, $\mathrm{pH} 6.5$ 以上では 1 として扱らことができる。

\section{3. 数值解析手法}

本研究に抢いてカドミウムの浄化解析を行ら場合, 水 素イオンとカドミウムイオンの 2 種類の化学種の濃度を 知る必要がある。まず，水素イオンの濃度を前報1) で示 した解析手法にしたがって計算し, 得られた水素イオン

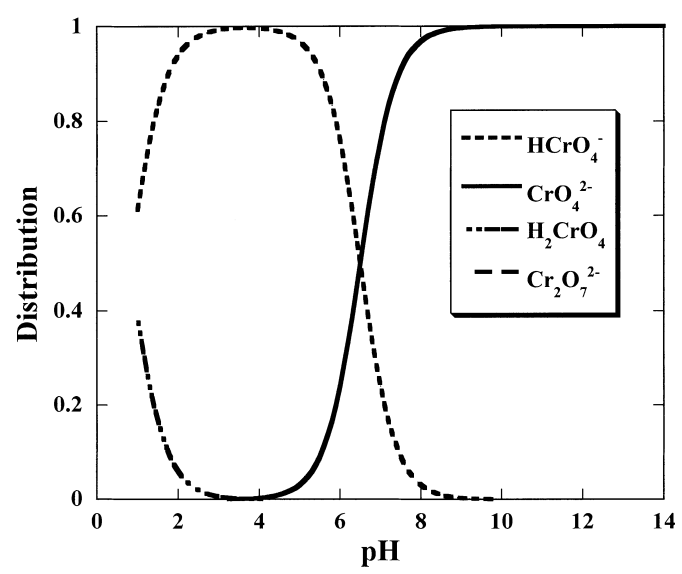

Fig. 3 Distribution of hexavalent chromium species as a function of $\mathrm{pH}$. $[\mathrm{Cr}]_{\text {total }}: 1.0 \times 10^{-3} \mathrm{~mol} / \mathrm{m}^{3}$

濃度 $(\mathrm{pH})$ 分布から Table 1 に示した関係を用いてカド ミウムの遅延係数を決定する。このような流れで各時間, 節点毎にカドミウムの遅延係数を更新し, カドミウム濃 度の経時変化を水素イオン濃度と同様に前報1) で示した 解析手法を用いて計算し, カドミウム濃度が目標值（本 研究に扣いては初期濃度の 1/10 の相対濃度で示す) 以下 を達成した時点で解析終了となる。一方，六価クロムの 浄化解析の場合, 本研究にお打る解析条件 (土堙 $\mathrm{pH}$ を 6.5 以上に保持する) では, 遅延係数を 1 と仮定できるこ とから, 水素イオン濃度に関係なく, 六価クロム濃度の 経時変化を計算し, 六価クロム濃度が目標值以下を達成 した時点で解析終了となる。

本研究では，前報 ${ }^{1)}$ で報告したように，濃度変化によ る密度変化が生じないと仮定することにより，浸透と移 流分散は別々の問題として取り扱らことができる。

電場土㙥中に掠ける物質の移流分散方程式は次のよう に表される。

$$
R_{\mathrm{d}} \theta \rho \frac{\partial C}{\partial t}=\frac{\partial}{\partial x_{\mathrm{i}}}\left(\theta \rho D_{\mathrm{ij}}^{*} \frac{\partial C}{\partial x_{\mathrm{j}}}\right)-\theta \rho V_{\mathrm{i}} \frac{\partial C}{\partial x_{\mathrm{i}}}-R_{\mathrm{d}} \theta \rho \lambda C-Q_{\mathrm{c}}
$$

ここで， $R_{\mathrm{d}}$ は遅延係数， $\rho$ は流体密度 $\left(\mathrm{kg} / \mathrm{m}^{3}\right), C$ は 濃度 $\left(\mathrm{mol} / \mathrm{m}^{3}\right), D_{\mathrm{ij}}^{*}$ は有効分散テンソル $\left(\mathrm{m}^{2} / \mathrm{s}\right), \quad V_{\mathrm{i}}$ は電 気打よび動水勾配による流速 $\left(V_{\mathrm{i}}=-\left(u^{*}+k_{\mathrm{e}}\right) \frac{\partial E}{\partial x_{\mathrm{i}}}-k_{\mathrm{h}} \frac{\partial h}{\partial x_{\mathrm{i}}}, u^{*}\right.$ は有効イオン移動度 $\left(\mathrm{m}^{2} / \mathrm{V} \cdot \mathrm{s}\right), k_{\mathrm{e}}$ は電気浸透係数 $\left(\mathrm{m}^{2} /\right.$ $\mathrm{V} \cdot \mathrm{s}), E$ は電位差 $(\mathrm{V}), h$ は水頭 $(\mathrm{m}), k_{\mathrm{h}}$ は透水係数 $(\mathrm{m} / \mathrm{s})$ を示している) $(\mathrm{m} / \mathrm{s}), \lambda$ は減衰定数 $(1 / \mathrm{s}), Q_{\mathrm{c}}$ は 源泉項を示す（ただし，本研究では土壌内での物質の分 解あるいは新たな生成がないことから, 式 (21) の右辺 第 3 項および第 4 項は無視できる)。また, 飽和・不飽和 浸透流方程式は次式で表される。 


$$
\begin{aligned}
\rho_{\mathrm{r}} \theta \gamma \frac{\partial C}{\partial t}+\rho\left\{\beta S_{\mathrm{S}}+C_{\mathrm{S}}(\theta)\right\} \frac{\partial \varphi}{\partial t} \\
=\frac{\partial}{\partial x_{\mathrm{i}}}\left\{\rho K_{\mathrm{ij}}^{\mathrm{S}} K_{\mathrm{r}}(\theta) \frac{\partial \varphi}{\partial x_{\mathrm{j}}}+\rho K_{\mathrm{i} 3}^{\mathrm{S}} K_{\mathrm{r}}(\theta) \rho_{\mathrm{r}}\right\}
\end{aligned}
$$

$\varphi$ は圧力水頭 $(\mathrm{m}), S_{\mathrm{S}}$ は比貯留係数 $(1 / \mathrm{m}), C_{\mathrm{S}}(\theta)$ は比 水分容量, $K_{\mathrm{ij}}^{\mathrm{s}}$ は飽和透水テンソル $(\mathrm{m} / \mathrm{s}), K_{\mathrm{r}}(\theta)$ は比透 水係数, $\rho_{\mathrm{f}}$ は溶媒の密度 $\left(\mathrm{kg} / \mathrm{m}^{3}\right), \rho_{\mathrm{r}}$ は密度比 $\left(\rho / \rho_{\mathrm{r}}\right), \gamma$ は溶質の密度比を示す。飽和領域では $\beta=1$, 不飽和領域 では $\beta=0$ である。最初に，濃度既知として Euler 法によ り飽和・不飽和浸透流解析を行い, 要素重心に打けるダ ルシー流速から節点の実流速を求める。次に流れ場既知 として Eulerian-Lagrangian法により移流分散解析を行い, 各時間ステップに抢ける濃度分布を求めた。

\section{4. 解析結果および考察}

\section{1 電極配列の影響}

動電学的土壌浄化法を実活染サイトに適用する場合, 電極材料抢よび電極をどのように配列するかは，重要な 操作因子となる。電極材料としては，基本的に化学的に 不活性で，導電性が良いものが使用される。陽極材料と してはグラファイト，イリジウムでコーテイングしたチ タン，白金などの酸に対して耐腐食性がある材料が使用 される。陰極材料には，塩基に対して耐腐食性があり， 導電性のよい材料が使用される。本研究では, 前報 ${ }^{1)}$ と 同様に 4 種類の電極配列について検討した。検討した 4 種類の基本電極配列を Fig. 4 に示す。ここで，各電極配
列を比較するために, 污染土壌の規模と総電極井戸数を ほぼ統一して各電極配列を配置し, 対象土壤からのカド ミウムおよび六価クロムの浄化解析を行うことによって 各電極配列の重金属の浄化効率を比較する。解析領域と しては，污染土壤面積を約 $900 \mathrm{~m}^{2}$ (約 $30 \mathrm{~m} \times 30 \mathrm{~m}$ )，その 外側に $2 \mathrm{~m}$ の非污染土壤領域を設定した。また，重金属 による污染部分を囲むように各基本電極を Fig. 5 のよう に配置した。ただし，Fig. 5 は後述する砂質粘土土壌を 対象とした場合で, 電極配置を圧力水頭で表示している。 カドミウムと六価クロムではイオン移動の方向が異なる ため, カドミウムの浄化を行う場合には圧力水頭が高い 地点を陽極井戸，低い地点を陰極井戸とし，一方，六価 クロムの浄化の場合には圧力水頭の高い地点を陰極井 戸，低い地点を陽極井戸として設定した。ただし，Fig. 5 はカドミウムの浄化を対象にした場合を示しており, 図 中に示す A は陽極を, C は陰極を示す。例えば, ACAC ……あるのは，図の左側より縦列単位で，陽極列，陰 極列の順で配列されていることを示す。カドミウムの浄 化の場合の各基本電極配列に抢ける電極井戸数および電 極間隔を Table 2 に示す。六価クロムの浄化の場合は, Table 2 の陽極数が陰極数になる。

カドミウムを浄化対象重金属とする場合, 土壌の $\mathrm{pH}$ がカドミウムの遅延係数に大きな影響を及ぼすため, 土 壤の $\mathrm{pH}$ は重要な要素となる。陽極で起こる水の電気分 解反応により発生する水素イオンが土壤内を移動する過 程で, 土壤の $\mathrm{pH}$ が低下することになる。本研究におい ては, 電極境界条件は, 電極にグラファイトのような化

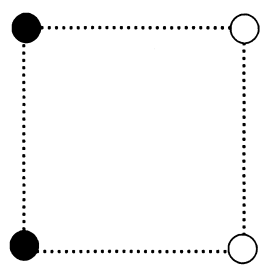

(a) Parallel

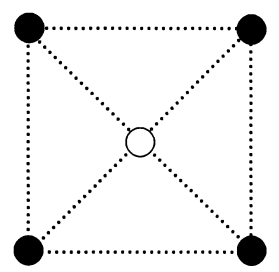

(b) Square

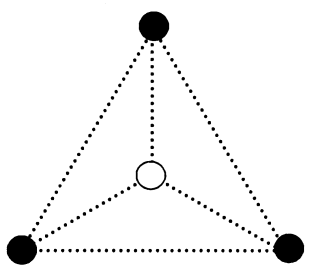

(c) Triangular

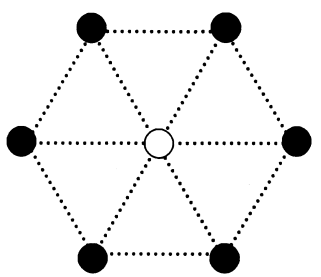

(d) Hexagonal

Anode

Cathode

Fig. 4 Electrode configuration.

Table 2 Electrode configuration, number of electrodes and electrode spacing used in numerical analysis for distributions of cadmium.

\begin{tabular}{lcc}
\hline Electrode configuration & $\begin{array}{c}\text { Total number of electrodes } \\
\text { (Number of anode) }\end{array}$ & Electrode spacing $(\mathrm{m})$ \\
\hline Parallel & $121(66)$ & 3.0 \\
Square & $113(64)$ & 3.0 \\
Triangular & $114(42)$ & 3.2 \\
Hexagonal & $114(78)$ & 3.2 \\
\hline
\end{tabular}


学的に不活性な物質を使用したと仮定し, 水の電気分解 反応のみを考光る。Faraday の法則によると電極反応によ る物質の生成割合は土壌内の電流通過量と等価であるこ と, また, 水の電気分解反応のみとしていることから, 陽極では水素イオンの発生のみを, 陰極では水酸化物イ オンの発生のみを考光る。ただし，陰極に抢いては水酸 化物イオンの土壤への浸出を防止するため, $\mathrm{pH} 7$ の固定 条件を採用した ${ }^{1,3,4)}$ 。陰極で発生する水酸化物イオンを硝 酸等により中和することで陰極からの水酸化物イオンの 土壇内への浸透を抑制し，陰極近傍での塩基性領域の形 成を防止する。これによりカドミウムの陰極近傍での水 酸化物等の生成が防止でき, カドミウムは速やかに陰極 井戸内に移行できるようになる ${ }^{3,4,12)}$ 。電極反応による物 質の生成割合は土壤内の電流通過量と等価であるとする と, Faraday の法則より陽極においては，I/F の一定濃度 フラックスが適用できる。ここで, $I$ は電流密度 $\left(\mathrm{A} / \mathrm{m}^{2}\right)$,

$F$ はファラデー定数（C/mol）を示す。

六価ク口ムを浄化対象重金属とする場合, 土壌の $\mathrm{pH}$ が 6.5 以上では遅延係数は 1 で一定と考兄られることか ら, 土壤の $\mathrm{pH}$ を 6.5 以上に保持する条件で解析を行っ た。したがって, 土壌中の六価クロムはすべて $\mathrm{CrO}_{4}^{2-}$ と して存在すると仮定した。また，解析領域の境界におい ては不透水境界条件を用いた。

対象土壌は, 砂に粘土抢よびシルトが混じった土壤(砂 質粘土土壤）とした。対象とした砂質粘土土壤の物性値 を Table 3 に示す。ただし, 流体密度は, 水を想定して $1.0 \times 10^{3} \mathrm{~kg} / \mathrm{m}^{3}$ とした。また, 体積含水率は, 飽和土壌を 対象としていることから間隙率と等しくなる。また, 解

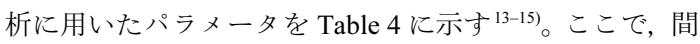
隙率 $($ 体積含水率 $(\theta))$ 拈よび電気浸透係数 $\left(k_{\mathrm{e}}\right)$ は, 両 土壤の代表的な值を用い, 屈曲性を表す要素 $(\tau)$ は, 式

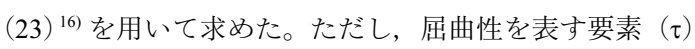
とは，物質が土壤内を移動する直線長さを $L_{\mathrm{s}}(\mathrm{m})$, 物質 が実際に移動する経路長を $L_{\mathrm{r}}(\mathrm{m})$ とすると， $\tau=L_{\mathrm{s}}{ }^{2} / L_{\mathrm{r}}^{2}$ で表されるものである。

$$
\tau(\theta)=\frac{G(\lambda)(\Theta)^{\mathrm{n}+1}}{(\Theta)_{\text {sat }}}
$$

$\Theta=\theta-\theta_{\mathrm{r}}$

ここで， $\Theta$ は有効（体積）含水率， $\theta_{\mathrm{r}}$ は残留（体積） 含水率を示し, 添字の sat は飽和土壤を示す。また, G ( $\lambda$ ）扣よび $\mathrm{n}$ は, 実験で得られた土壤間隙水の電気伝導 度と有効（体積）含水率の関係から導かれるパラメータ

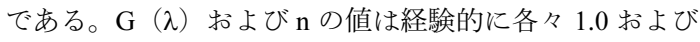
0.5 といら值が与えられて和り, さらに, 残留 (体積) 含 水率 $\left(\theta_{\mathrm{r}}\right)$ は零として取り扱光ること ${ }^{16)}$, また，本研究 では飽和土壌を対象としていることから，有効（体積）
Table 3 Characteristics of sandy/clayey soils.

\begin{tabular}{lc} 
Volumetric water content $\theta$ & 0.35 \\
Tortuosity factor $\tau$ & 0.59 \\
Fluid density $\left(\mathrm{kg} / \mathrm{m}^{3}\right) \rho$ & $1.0 \times 10^{3}$ \\
Hydraulic conductivity $(\mathrm{m} / \mathrm{s}) k_{\mathrm{h}}$ & $1.0 \times 10^{-5}$ \\
Coefficient of electroosmotic permeability & $3.6 \times 10^{-9}$ \\
$\left(\mathrm{~m}^{2} / \mathrm{V} \cdot \mathrm{s}\right) k_{\mathrm{e}}$ & \\
\hline
\end{tabular}

Table 4 Model parameters.

\begin{tabular}{lc}
\hline Initial pH & 6.5 \\
Diffusion coefficient of $\mathrm{H}^{+}\left(\mathrm{m}^{2} / \mathrm{s}\right) D_{\mathrm{H}^{+}}$ & $\left.9.31 \times 10^{-9} 13\right)$ \\
Ionic mobility of $\mathrm{H}^{+}\left(\mathrm{m}^{2} / \mathrm{V} \cdot \mathrm{s}\right) u_{\mathrm{H}}^{+}$ & $\left.3.62 \times 10^{-7} 13\right)$ \\
Retardation factor of $\mathrm{H}^{+} R_{\mathrm{d}}$ & 1.0 \\
Diffusion coefficient of $\mathrm{Cd}^{2+}\left(\mathrm{m}^{2} / \mathrm{s}\right) D_{\mathrm{Cd}}{ }^{2+}$ & $7.19 \times 10^{-10} *$ \\
Ionic mobility of $\mathrm{Cd}^{2+}\left(\mathrm{m}^{2} / \mathrm{V} \cdot \mathrm{s}\right) u_{\mathrm{Cd}}{ }^{2+}$ & $\left.5.60 \times 10^{-8} 14\right)$ \\
Diffusion coefficient of $\mathrm{CrO}_{4}{ }^{2-}\left(\mathrm{m}^{2} / \mathrm{s}\right)$ & $\left.1.07 \times 10^{-9} 15\right)$ \\
$D_{\mathrm{Cro} 4}{ }^{2-}$ & \\
Ionic mobility of $\mathrm{CrO}_{4}{ }^{2-}\left(\mathrm{m}^{2} / \mathrm{V} \cdot \mathrm{s}\right) u_{\mathrm{CrO} 4^{2-}}$ & $8.46 \times 10^{-8 *}$ \\
\hline
\end{tabular}

*calculated from Einstein relation.

含水率 $(\Theta)$ を間隙率（体積含水率 $(\theta)$ ) 飞置き換える ことができ，これらの值を用いて式（23）により屈曲性 を表す要素 $(\tau)$ を求めた。

このような条件の下で砂質粘土土䗙に対して浄化解析 を行った。ただし，陽極／陰極間の電場強度は, $100 \mathrm{~V} /$ $\mathrm{m}$ 一定とした。Fig. 6 は, 三角形型電極配列を例として, カドミウムの浄化の進行状沉を示したものである。ただ し, 濃度分布は初期カドミウム濃度を 1 として相対濃度 で示している。また，Fig.7 特よび Fig. 8 は，各電極配列 でのカドミウム拈よび六価クロムの浄化の進行の経時変 化を示している。本研究では, 重金属の浄化の程度を表 す指標として土壌浄化割合といら指標を用いた。土壌浄 化割合とは，ある時間までに浄化された重金属の累積量 と初期の重金属の総量の割合を表している。前報りにお いて土壌の酸性化は，陰極を中心に陽極を三角形，四角 形および六角形の多角形構造に配置するほうが, 並列型 の電極配置よりも酸性化が迅速に進行することを報告し た。土壌の酸性化が浄化効率に強く影響するカドミウム の浄化に扔いても, 土壌の酸性化と同様に陰極を中心に 陽極を三角形, 四角形拉よび六角形の多角形構造に配置 するほらが，並列型より浄化が迅速に進行していること が分かる。このことから最も基本的な電極配列である並 列型の電極配列よりも陰極を中心に陽極を多角形構造に 配置するほらがカドミウムの浄化効率に優れていること が分かる。これは, 主として並列型の電極配列では隣接 する陽極と陰極間での水素イオンの線的な拡がりが主体 で，面的な拡がりが多角形型の電極配列と比較して劣る ことが原因として考光られる。一方，六価クロムの場合 も, 陽極を中心に陰極を多角形構造に配置するほらが, 並列型よりも浄化が迅速に進行することが分かる。カド 


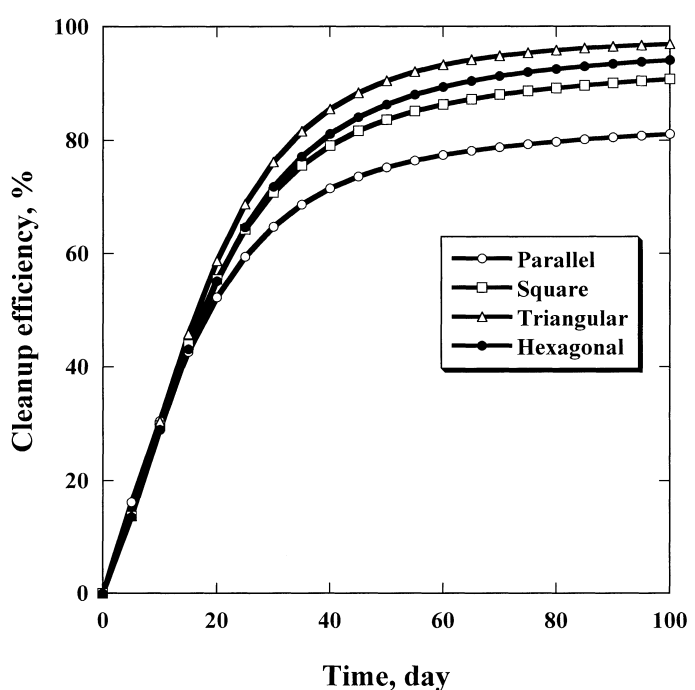

Fig. 7 Effect of electrode configuration on cleanup efficiency of cadmium from sandy/clayey soil.

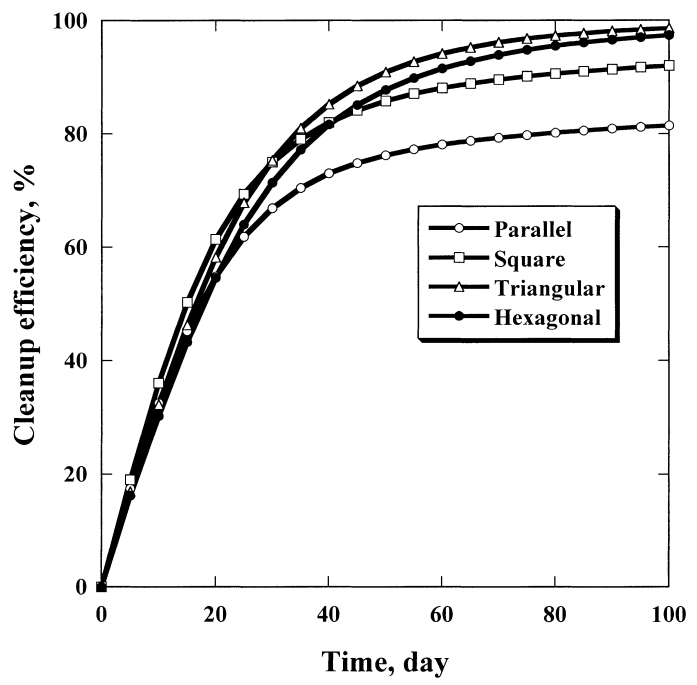

Fig. 8 Effect of electrode configuration on cleanup efficiency of hexavalent chromium from sandy/clayey soil.

ミウムおよび六価クロムのいずれにおいても，浄化はま ず陽極と陰極を結ぶ領域で最も迅速に進行し，重金属が 回収される側の電極（カドミウムでは陰極，六価クロム では陽極）間を結ぶ領域で浄化の進行が遅くなることか ら, この領域に抢ける浄化の改善が必要になる。

\section{2 電極間電場強度の影響}

4.1 と同様に約 $900 \mathrm{~m}^{2}$ の污染された土壤を対象に, 三 角形型電極配列に扣ける電極間電場強度が浄化に与える 影響について検討した。ただし，陽極と陰極の設置距離 は $3.0 \mathrm{~m}$ 一定とした。電極間電場強度を $50 \mathrm{~V} / \mathrm{m}, 100 \mathrm{~V} / \mathrm{m}$

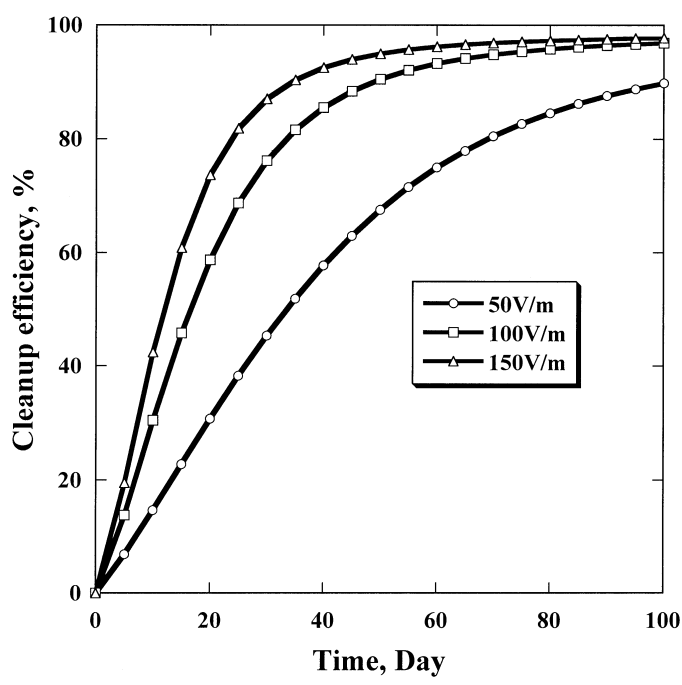

Fig. 9 Effect of electric field strength on cleanup efficiency of cadmium from sandy/clayey soil with triangular electrode configuration.

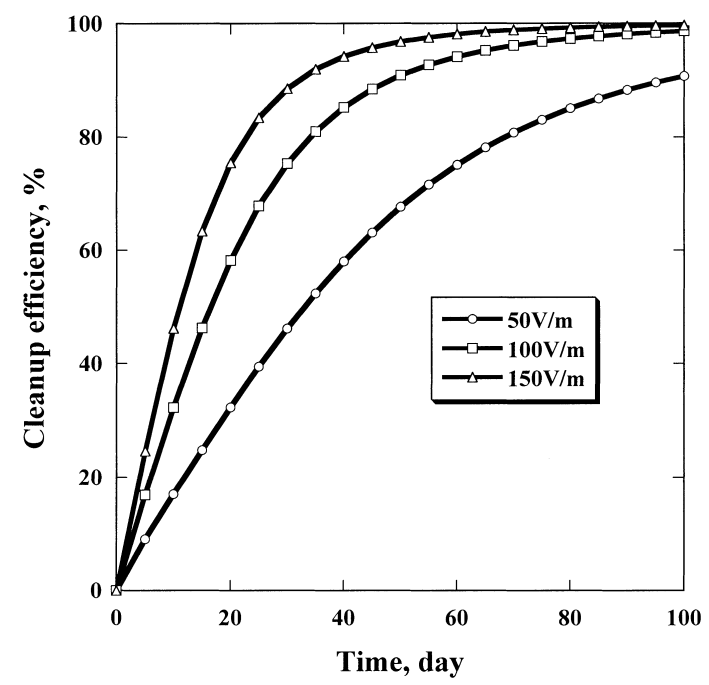

Fig. 10 Effect of electric field strength on cleanup efficiency of hexavalent chromium from sandy/clayey soil with triangular electrode configuration.

および $150 \mathrm{~V} / \mathrm{m}$ に設定した場合のカドミウムおよび六価 クロムの土壌浄化割合の経時変化を Fig. 9 および Fig. 10 に示す。Fig. 9 および Fig. 10 から分かるように, 電極間 電場強度が $50 \mathrm{~V} / \mathrm{m}$ の場合, カドミウムおよび六価クロム の浄化に拈いて土㙋浄化割合 $90 \%$ 達成するのに各々約 100 日を要したのに対し，電極間電場強度が $100 \mathrm{~V} / \mathrm{m}$ の 場合は, 土䁃浄化割合 $90 \%$ を達成するのに各々約 50 日 であった。また， $150 \mathrm{~V} / \mathrm{m}$ の場合，土壌浄化割合 $90 \%$ を 達成するのに各々約 30 日报よび約 35 日を要した。特に, 電極間電場強度を $50 \mathrm{~V} / \mathrm{m}$ から $100 \mathrm{~V} / \mathrm{m}$ に増加させた場合 


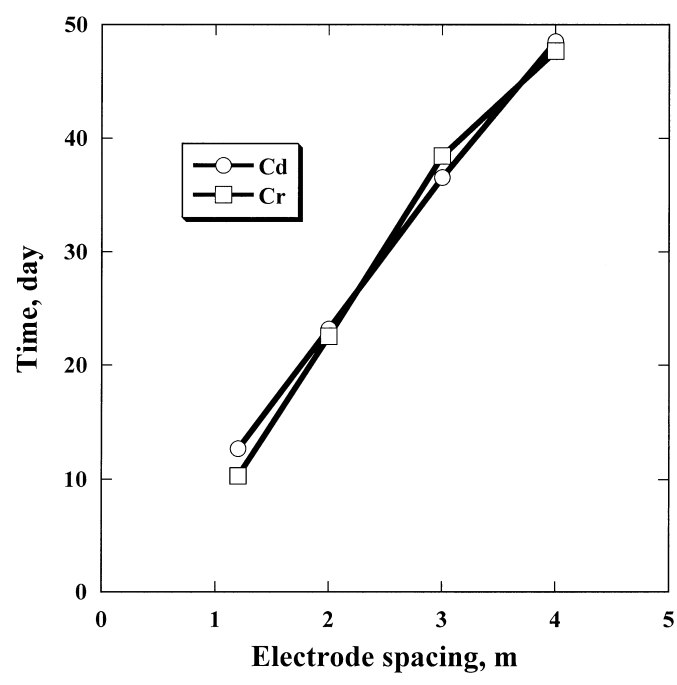

Fig. 12 Relationship between treatment time achieved cleanup efficiency of $80 \%$ and electrode spacing with triangular electrode configuration.

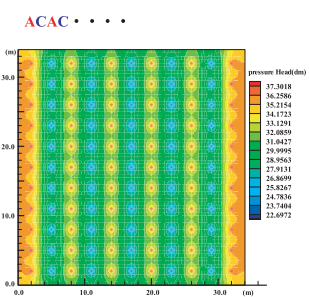

(a) Parallel

ACCACC $\cdots$

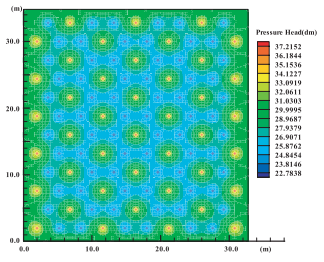

(c) Triangular

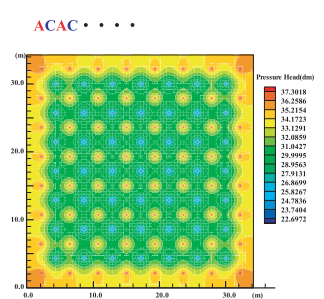

(b) Square

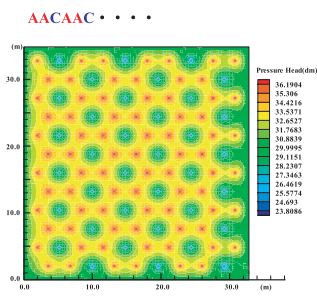

(d) Hexagonal
Fig. 5 Electrode arrangement indicated with pressure head (cadmium contaminated sandy/clayey soil).

の方が，電極間電場強度を $100 \mathrm{~V} / \mathrm{m}$ から $150 \mathrm{~V} / \mathrm{m}$ に増加 させ場合より，浄化効率の大幅な改善が見られる。ただ し, 電極間電場強度の設定については, 浄化効率だけで なく通電中の地盤温度なども考慮して決定する必要があ ると考えられる。

\section{3 電極間距離の影響}

三角形型電極配列における陽極と陰極の設置距離が浄 化に与える影響について検討した。解析領域は, 縦 $16 \mathrm{~m}$, 横 $15 \mathrm{~m}$ とし, その内側に $13 \mathrm{~m} \times 13 \mathrm{~m}$ の污染領域を配置 した。また, Fig. 11 に, カドミウムを浄化する場合を例

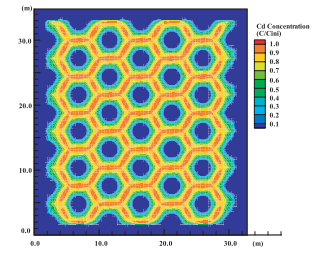

(a) 20day

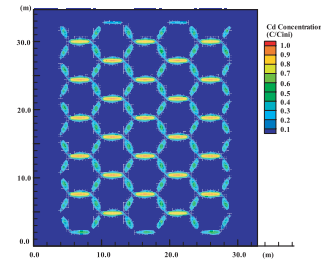

(c) 60day

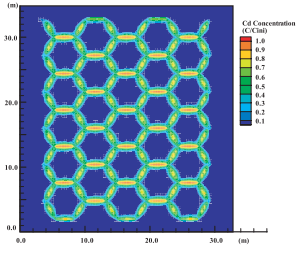

(b) 40day

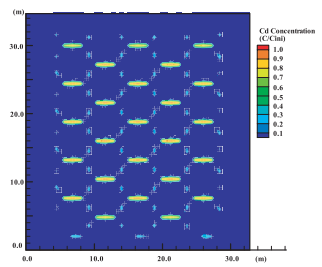

(d) 80day
Fig. 6 Time history of cleanup of cadmium from sandy/ clayey soil with triangular electrode configuration.

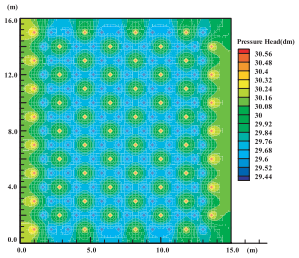

(a) $1.2 \mathrm{~m}$

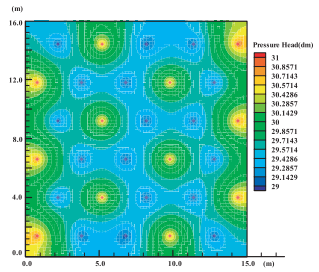

(c) $3.0 \mathrm{~m}$

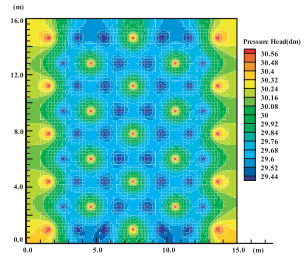

(b) $2.0 \mathrm{~m}$

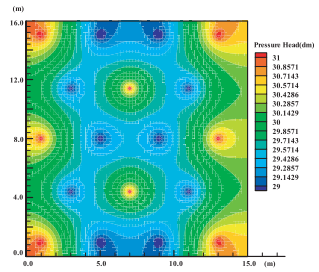

(d) $4.0 \mathrm{~m}$
Fig. 11 Triangular electrode arrangement in different electrode spacing (cadmium contaminated sandy/clayey soil).

として，各電極間距離における電極の配置を示す。ただ し，六価クロムを浄化する場合には，Fig. 11 の陽極と陰 極の配置が逆になる。また，電極間電場強度は $100 \mathrm{~V} / \mathrm{m}$ 一定である。Fig. 12 に，電極間距離を $1.2 \mathrm{~m}, 2.0 \mathrm{~m}, 3.0$ $\mathrm{m}$ 抢よび $4.0 \mathrm{~m}$ に設定した場合の各々について, 土壌浄 化割合が $80 \%$ に達するのに要した時間と電極間距離の関 係を示す。Fig. 12 から, 土壌浄化割合 $80 \%$ を達成するの に要した時間と電極間距離には比例関係が認められ，陽 極と陰極の設置距離が長くなるほど浄化に要する時間が 増加する。このように, 浄化に要する時間は, 電極間距 離に強く依存することが分かる。ただし, 実際に污染サ イトで浄化を実施する場合には，土壤の浄化効率の面か 
らだけでなく，ボーリングする電極井戸数や使用する電 極数など，コスト面も考慮して適切な電極間距離を設定 する必要がある。

\section{5. 結言}

電流（電位）によって誘起されるイオン移動や電気 浸透流による物質移動を, 電気的に発生する移流と考光, 流量（水頭）に置き換えた数值解析手法を適用し，動電 学的手法による重金属の浄化に与える電極配列などの影 響について検討し，以下の結果が得られた。

1) カドミウムを浄化する場合, 最も基本的な電極配列で ある並列型の電極配置よりも陰極を中心に陽極を多角 形構造に配列するほうが浄化効率に優れている。また, 六価クロムを浄化する場合も並列型よりも陽極を中心 に陰極を多角形構造に配置するほうが浄化効率に優れ ている。

2) 浄化効率は電極間電場強度が増加するほど高くなる。 特に, $100 \mathrm{~V} / \mathrm{m}$ 以下で電極間電場強度が浄化効率に与 える影響が強い。

3) 浄化に要する時間は，電極間距離に強く依存し，陽極 と陰極の設置距離が長くなるほど浄化に要する時間は 長くなる。

\section{謝 辞}

本研究の一部は文部科学省科学研究費補助金（基盤研 究（B)，No. 15360475）の補助を受けたことを明記する。

\section{References}

1) M. Niinae, Y. Aoki, K. Aoki: Resources Processing, 52, pp. 136-144 (2005)

2) N. Tanaka and H. Sugi: Saku Keisei Hanno-Bunseki Kagaku ni-okeru Ouyo, Sangyo Tosho (Tokyo), pp. 272319 (1992)

3) M. Niinae, T. Aoe, T. Sugano, K. Aoki: Journal of the Mining and Materials Processing Institute of Japan, 117, pp. 127-132 (2001)

4) M. Niinae, T. Aoe, T. Sugano, K. Aoki: Journal of the Mining and Materials Processing Institute of Japan, 117, pp. 653-657 (2001)

5) Japanese Association of Groundwater Hydrology: Chikasui Suishitsu no Kiso, Rikogaku Tosho (Tokyo), pp.6175 (2002)

6) S. Iwata and Z. Uchijima: Kankyo Dojyo Butsurigaku ITsuchi to Mizu no Butsurigaku, Nourin Toukei Kyoukai (Tokyo), pp. 100-105 (2001)

7) P.A. Domenico and F.W. Schwartz: Chikasui no Kagaku II-Chikasuikankyogaku (translation supervised by Y. Ohnishi), Dobokukogakusha (Tokyo), pp.45-53 (1996)

8) H.M. Selim and D.L. Sparks: Heavy Metals Release in Soils, Lewis Publishers (Boca Raton), pp. 55-88 (2001)

9) G.R. Eykholt and D.E. Daniel: Journal of Geotechnical Engineering, 120, pp. 797-815 (1994)

10) E.A. Jenne: Adsorption of Heavy Metals by Geomedia, Academic Press, pp. 427-443 (1998)

11) M. Nakano: Tsuchi no Bussitsu Idogaku, University of Tokyo Press (Tokyo), pp. 52-54 (1991)

12) M. Niinae, T. Aoe, T. Sugano, K. Aoki: Journal of the Mining and Materials Processing Institute of Japan, 116, pp. 855-860 (2000)

13) A.N. Alshawabkeh and Y. Acar: Journal of Environmental Science and Health, A27, pp. 1835-1861 (1992)

14) The Chemical Society of Japan: Kagaku Binran, Maruzen (Tokyo), p. 862 (1958)

15) B.S. Haran, B.N. Popov, G. Zheng, R.E. White: Journal of Hazardous Materials, 55, pp. 93-107 (1997)

16) E.D. Mattson, R.S. Bowman, E.R. Lindgren: Journal of Contaminant Hydrology, 54, pp. 99-120 (2002) 